\title{
Preliminary report on the Early Pleistocene vertebrate sites of Beremend Crystal Cave (Beremend 16, South Hungary) and on their palaeoecological importance
}

\author{
Piroska Pazonyi ${ }^{1}$, Mária TrembeczkI ${ }^{2}$, Lukács MészÁros ${ }^{3}$, Zoltán Szentesi ${ }^{4}$ \\ ${ }^{1}$ MTA-MTM-ELTE Research Group for Paleontology, \\ H-1083 Budapest, Ludovika tér 2, Hungary.E-mail: pinety@gmail.com \\ ${ }^{2}$ Saint Margaret Catholic Grammar School, \\ H-1114 Budapest, Villányi út 5-7, Hungary.E-mail: trembeczki.maria@szmg.hu \\ ${ }^{3}$ Department of Palaeontology, Eötvös University, \\ H-1117 Budapest, Pázmány Péter sétány 1/c, Hungary.E-mail:lgy.meszaros@gmail.com \\ ${ }^{4}$ Department of Palaeontology and Geology, Hungarian Natural History Museum, \\ H-1083 Budapest, Ludovika tér 2, Hungary.E-mail: crocutaster@gmail.com
}

\begin{abstract}
Formerly, the Early Pleistocene vertebrate material collected independently from 15 different sampling sites of Beremend Crystal Cave were merged together and treated as a whole, under the name of Beremend 16. However, the thorough analysis of the fauna of each separate sampling site revealed considerable taxonomic, palaeoecological and stratigraphic differences, which render the aforementioned unification unjustified. Diverse and sparse assemblages were recognized based on the fossil richness and taxonomic composition of the samples. Some of the assemblages contain only bats, whereas others consist of further small mammals besides the bats as well as herpetofaunal elements. The compositional dissimilarities suggest taphonomical or age differences comparing the sites. Based on our environmental reconstruction, a water body varying in size was always present in the vicinity of the cave during the studied time period, which was surrounded by an open or a more closed vegetation depending on the slight climatic changes. Our stratigraphic analysis showed that most of the sites can be dated between 1.5 and 1.2 Ma. In the case of two sites, it was possible to make a more precise age estimation (1.2 Ma) based on the appearance of the white-toothed shrew, Crocidura obtusa. With 4 figures and 4 tables.
\end{abstract}

Key words - Beremend, Early Pleistocene, palaeoecology, small vertebrates, stratigraphy

\section{INTRODUCTION}

Szőlö Hill of Beremend is located approximately $9 \mathrm{~km}$ south of the Villány Hills and municipality Villány, in South Hungary. The altitude of this flat, loesscovered limestone hill was $174 \mathrm{~m}$ before the mining activity. The limestone quarry of Beremend has yielded classic palaeovertebrate faunas, which were studied for more than a century by Salamon J. Petényi, Miklós Kretzoi, and Dénes Jánossy, 
meanwhile the mollusc faunas were studied by Endre Krolopp (see JÁNOssY 1986). During that time, quarrying unearthed fossil-bearing caves and cavities in the Late Cretaceous limestone, which resulted in rescue excavations (KRETzOI 1956; JÁnossy 1986; Kordos 1991; PongráCZ 1999; CsÁszÁr \& Kordos 2004). According to Kretzoi (1969) and Kretzoi \& PÉcsi (1982), these sites represent the Late Pliocene Beremendian Biochronological Phase; however, according to KROLOPP (1990), their age most likely spans up to the beginning of the Early Pleistocene (Early Villanyian Biochronological Phase).

Vertebrate remains were described first from Szőlő Hill by PetéNy (1864). At the beginning of the twentieth century, Tivadar Kormos, Lajos Méhely and later Jenő Noszky collected palaeovertebrate material from various sites on the hill (JÁNossy 1996). During subsequent studies, 26 fossil-bearing cavities were discovered in the quarry (KRETZOI 1956; JÁNossy 1986; Kordos 1991; Pongrácz 1999; CsÁszár \& Kordos 2004) (PAzonyi et al. 2016, Fig. 1). Most recently, new material was collected, and a scientific revision was based on the newly found and previously collected remains (PAzONY et al. 2016; SZENTESI 2016; TREMBECZKi et al. 2018).

Beremend Crystal Cave was discovered at the end of 1984 by Mihály Magusits; the exploration in the same and the following year demonstrated that it forms a part of a larger system (TAKÁCs-BOLNER 1986). According to recent studies, Beremend Crystal Cave is a typical hydrothermal cave system, which was formed as a result of mixing corrosion. It has several levels and a labyrinth-type network of passages characterized by sudden size changes. It is exceptionally rich in minerals, spherical cavities and other morphologies, which were created by hydrothermal processes (VIGASSY et al. 2010). Vertebrate finds from the cave were mentioned first by TAKÁCs-BOLNER (1986), but collecting and scientific studies have only been done later by JÁnOssy $(1992,1996)$ and György Topál (JÁNOSSY \& Topál 1985; JánOSSY et al. 1987; JÁNOSSY 1996). JÁNOSSY $(1992,1996)$ discussed all material from Beremend Crystal Cave as a whole as Beremend 16, and all that were found outside, above the entrance as Beremend 17. He also considered that the material within the cave was infiltrated from the fissure fillings which can be found outside (JÁNOSSY et al. 1987). Later studies suggested that considerable differences can be observed when comparing the vertebrate assemblages of the individual sampling sites (SzENTESI 2016; TREMBECZKI et al. 2018), thus the unification of the assemblages of Beremend 16 (and possibly 17) is not justified.

The aims of the current study are to compare the taxonomic composition of each sampling site within the cave with each other (addressing also the abundance of each species within an assemblage) and to draw palaeoecological and stratigraphic conclusions based on the small mammals and herpetofaunal elements. 


\section{MATERIAL AND METHODS}

Dénes Jánossy and György Topál collected fossils from Beremend Crystal Cave altogether six times between 1985 and 1987. Their excavations yielded 20 small vertebrate-rich red clay samples (Fig. 1). The material was discussed by them as a whole, under the name of Beremend 16. Fortunately though, the original numbering of the sampling sites is still noted besides the material stored within the collections of the Department of Palaeontology and Geology at the Hungarian Natural History Museum, and their field report has also been archived. These documents, on the one hand, reveal that not all of the numbers represent individual sampling sites. There were places where they went collecting repeatedly, giving a new number to each new sample during every occasion (Fig. 1). On the other hand, the documentation reveals that György Topál recognized notable ecological differences comparing the assemblages of different sampling sites (JÁNOSSY et al. 1987). Based on this information, we were able to recognize 15 individual sampling sites and study their material separately. The small mam-

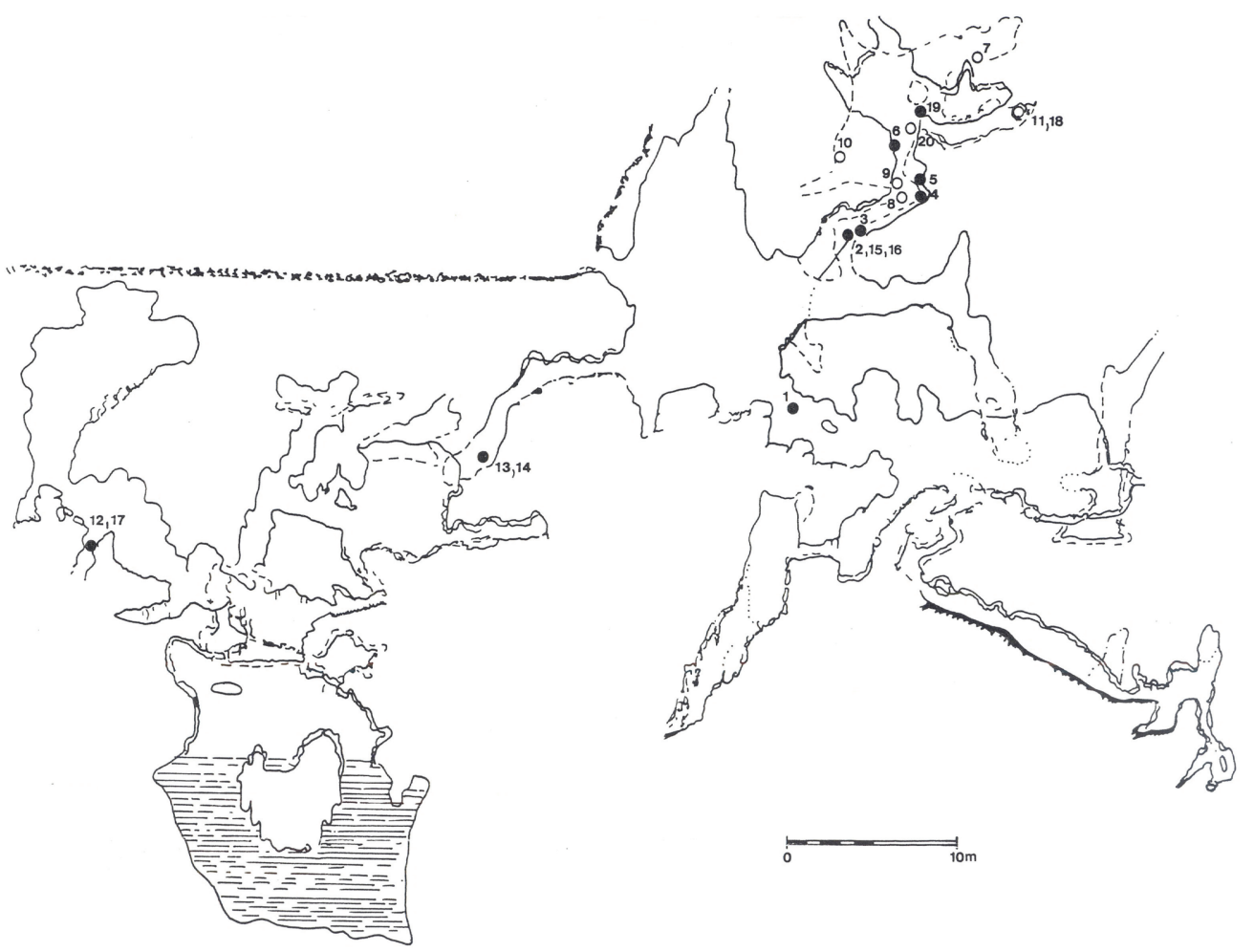

Fig. 1. Cross-section of Beremend Crystal Cave (Beremend 16) with the location of the fossil sites (numbers of the original samples are indicated) (JÁnOssY et al. 1987) 
mals and the herpetofaunal elements were revised here, whereas the large mammals were only mentioned on the basis of the original field report (JÁNOSSY et al. 1987; Table 1).

In this article, when mentioning an individual sampling site within the cave, we always indicate all numbers that represent samples collected from the same place, such as $2 / 15 / 16$. However, in order to avoid confusion and long site names, we will not mention that these were all described as Beremend 16 before, thus the full citation in the latter case should look like as Beremend 16/2, Beremend 16/15 and Beremend 16/16.

During the taxonomic analysis, we determined all elements from the formerly only partially studied herpetofauna from Beremend Crystal Cave. Furthermore, with the addition of newly found specimens that were recovered from the previously collected, but unpicked sediment samples, we revised the entire small mammal fauna. By specifying minimum number of individuals (MNI) for each taxon in each site (Table 1), a palaeoecological analysis became possible.

The determination of the climate tolerance of most bat species was based on their current distribution (BIHARI et al. 2007), as most species are still extant, apart from four. These ecological characteristics are presumed at Pliocene and Pleistocene sites (Popov 2004; Gunnell et al. 2011; Travnic Kova 2016).

Eptesicus nilssoni and Myotis dasicneme are considered to be cold preferring species, because they live mainly in northern Eurasia. To the south, they occur along the latitudes of Central Europe (Table 2).

All species of the genus Rhinolophus prefer warm climate; they are most frequent today in the Mediterranean Region and Africa. Their occurrence extends north up to the Carpathian Basin. Miniopterus schreibersi is found in many warm regions of the world, with central France, southern Germany, and Slovakia as the northern border of its habitat in Europe. Myotis blythi is a typical species of southern Europe, Asia Minor, and the Middle East.

Many species have a broad temperature tolerance. Plecotus abeli is extinct, but its descendant, Plecotus auritus occurs from North Africa to latitude $64^{\circ} \mathrm{N}$ in Europe (Woloszyn 1987). Recent Myotis mystacinus, M. nattereri, M. daubentoni, $M$. brandti, and $M$. bechstein species also have the same distribution.

$M$. praevius and $M$. steiningeri are extinct, and the occurrence of the recent Myotis schaubi is reported only in some areas of the Middle East, thus their ecological tolerances are hardly known.

Most bats are less indicative of climate than the typical ecotope which is definitely required by them. Myotis blythi and Miniopterus schreibersi are the inhabitants only of open grasslands. Regardless of the surrounding vegetation, Myotis daubentoni and $M$. dasycneme occur along larger water bodies. Eptesicus nilssoni, Myotis nattereri, M. bechstein, M. brandti, M. mystacinus, and Rhinolophus euryale 


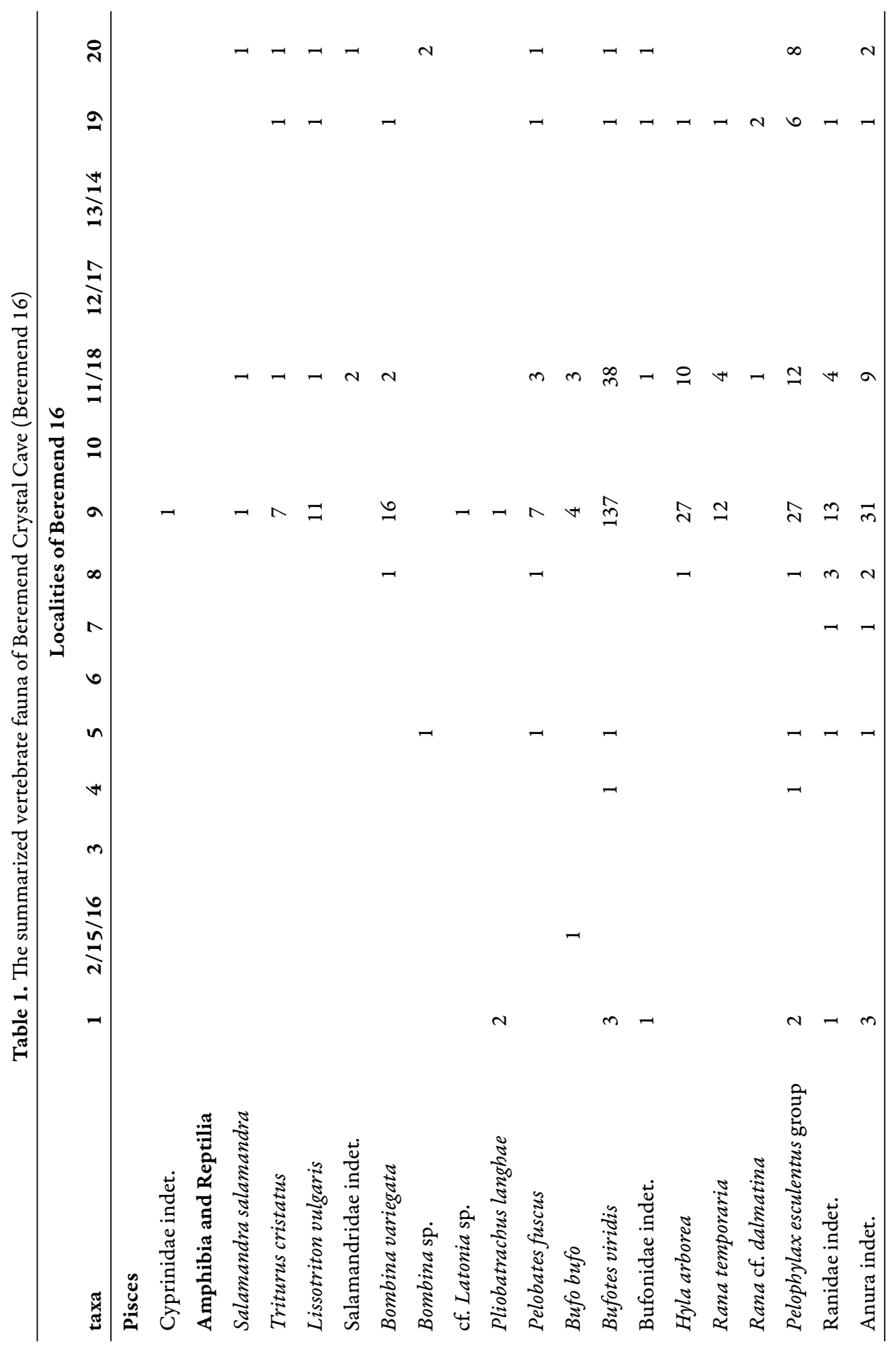




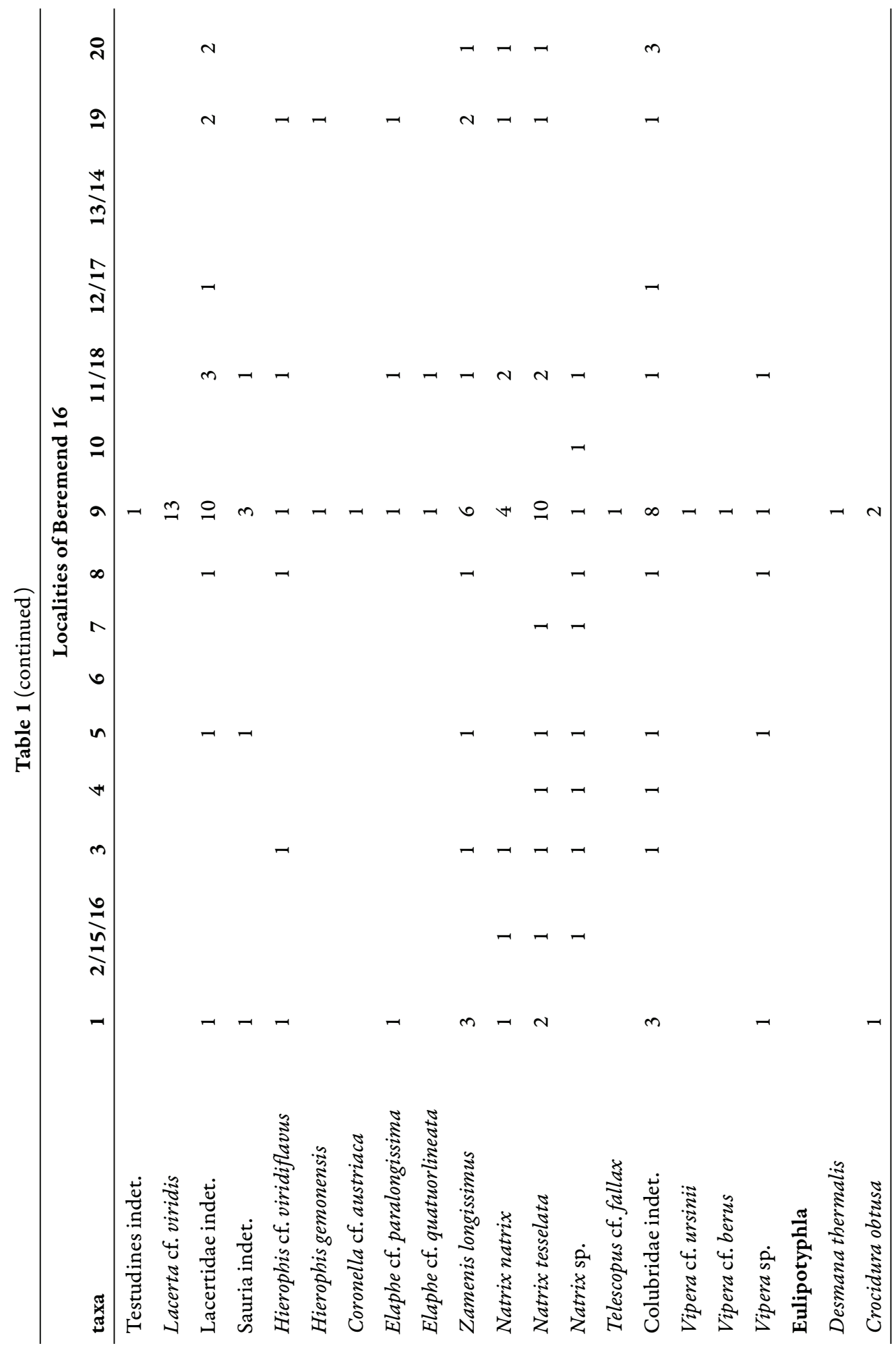




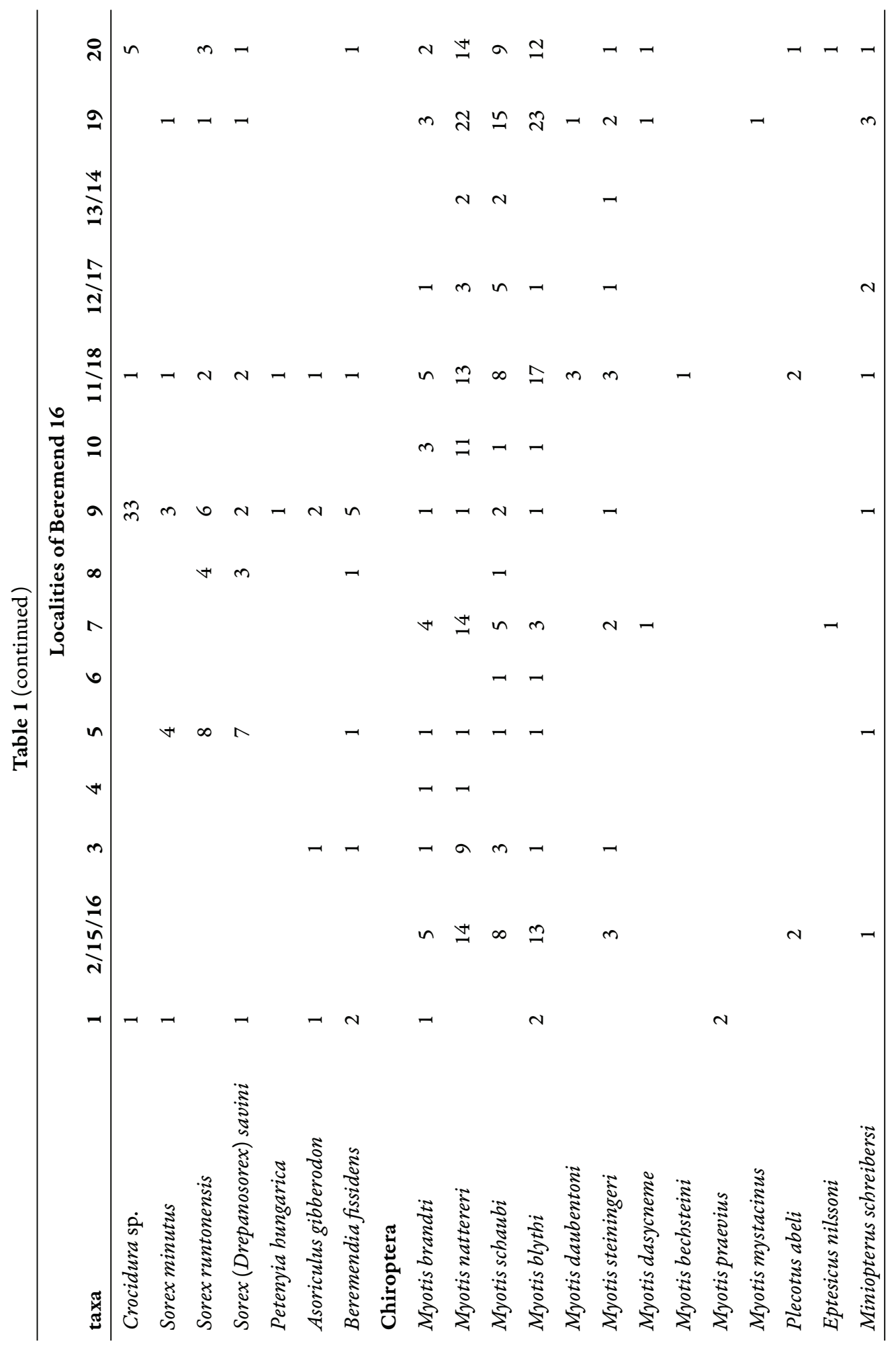




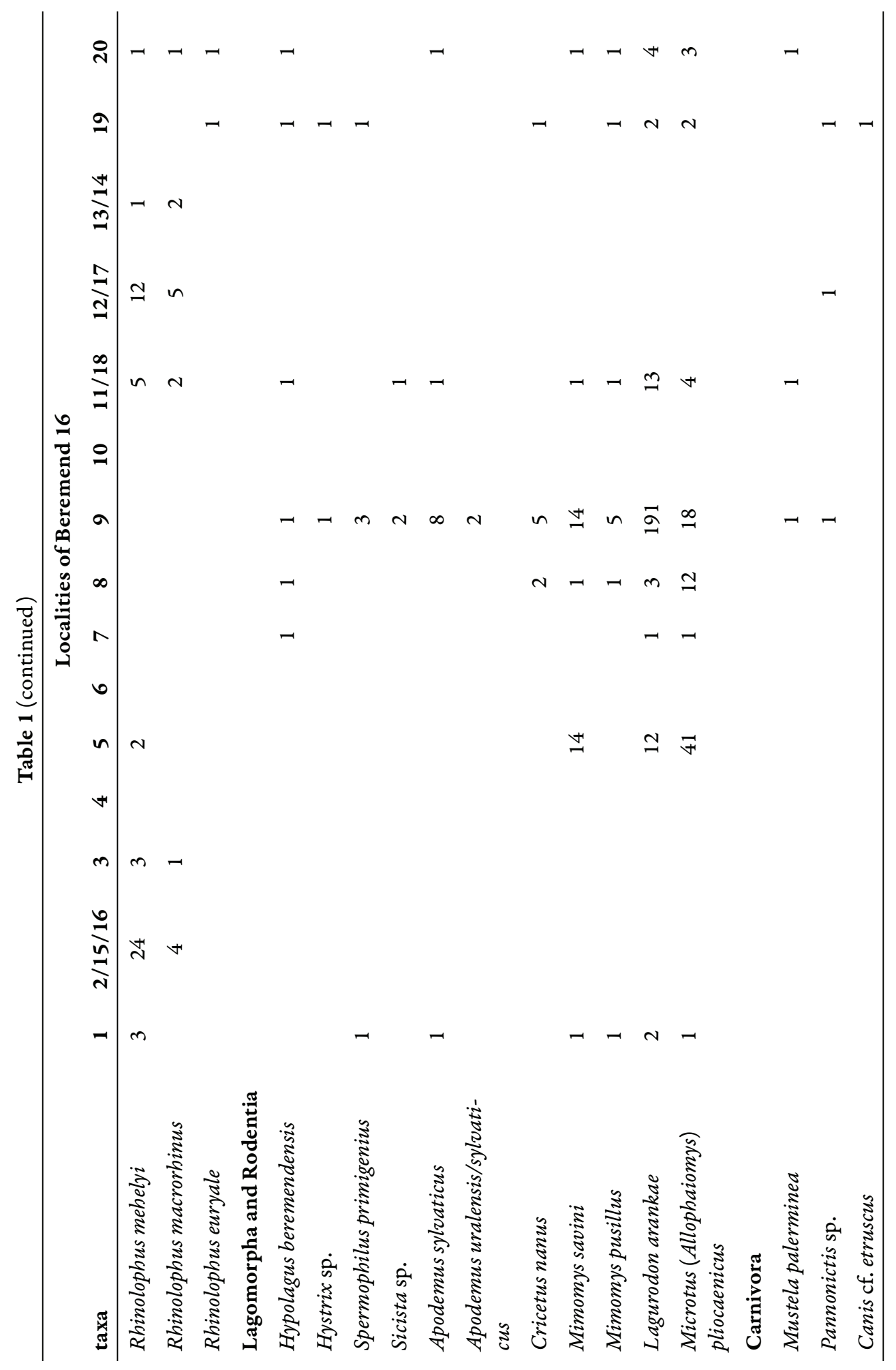




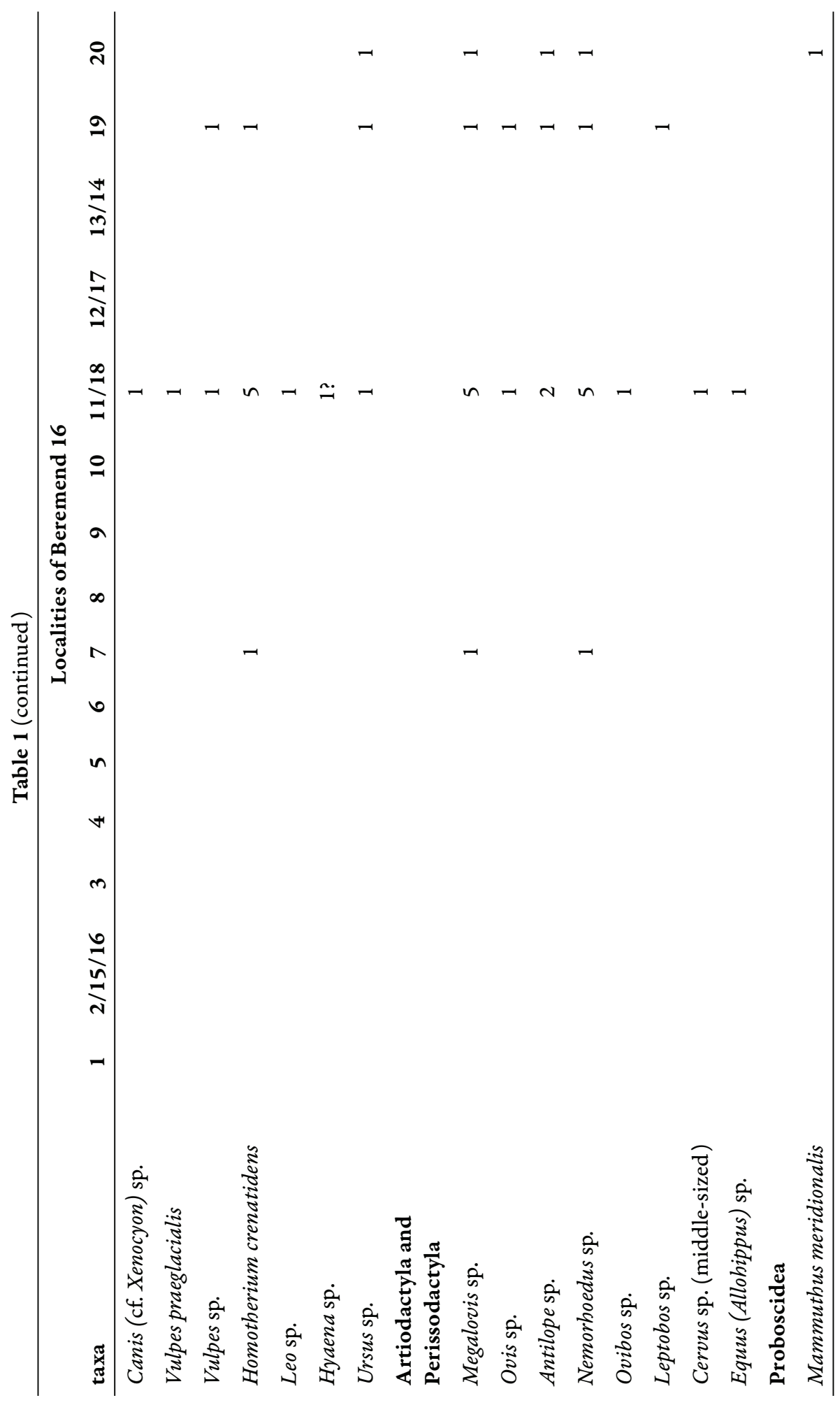


Table 2. Climatic and environmental preferences of the small vertebrates recovered from Beremend Crystal Cave (Beremend 16) (ARNold \& Ovenden 2002; Eggert 2002; Thirion et al. 2002; Duguet \& Melki 2003; Denö̈l 2004; Popov 2004; Blain \& Villa 2006; Böhme et al. 2006; BIHARI et al. 2007; GUNNELL et al. 2011; ŽAGAR et al. 2011; CARIsio et al. 2014; Miró et al. 2016; Travnickova 2016)

\begin{tabular}{|c|c|c|}
\hline Species & Climate & Vegetation/Ecotope \\
\hline Salamandra salamandra & widespread & closed \\
\hline Triturus cristatus & widespread & closed \\
\hline Lissotriton vulgaris & widespread & closed \\
\hline Bombina variegata & widespread & water \\
\hline Pliobatrachus langhae & unknown & water \\
\hline Pelobates fuscus & widespread & open \\
\hline Bufo bufo & widespread & open \\
\hline Bufotes viridis & widespread & open \\
\hline Hyla arborea & widespread & closed \\
\hline Rana temporaria & widespread & closed \\
\hline Rana cf. dalmatina & widespread & closed \\
\hline Pelophylax esculentus group & warm & water \\
\hline Lacerta cf. viridis & warm & open \\
\hline Hierophis cf. viridiflavus & warm & closed \\
\hline Hierophys gemonensis & warm & open \\
\hline Coronella cf. austriaca & widespread & opportunist \\
\hline Elaphe cf. paralongissima & warm & unknown \\
\hline Elaphe cf. quatuorlineata & warm & closed \\
\hline Zamenis longissimus & warm & closed \\
\hline Natrix natrix & widespread & water \\
\hline Natrix tesselata & warm & water \\
\hline Telescopus cf. fallax & warm & open \\
\hline Vipera cf. ursinii & warm & open \\
\hline Vipera cf. berus & widespread & closed \\
\hline Desmana thermalis & warm & water \\
\hline Crocidura sp. & warm & open \\
\hline Sorex minutus & cold & closed \\
\hline Sorex runtonensis & cold & open \\
\hline Sorex (Drepanosorex) savini & unknown & water \\
\hline Petenyia hungarica & widespread & opportunist \\
\hline Asoriculus gibberodon & widespread & open \\
\hline
\end{tabular}


Table 2 (continued)

\begin{tabular}{|c|c|c|}
\hline Species & Climate & Vegetation/Ecotope \\
\hline Beremendia fissidens & widespread & water \\
\hline Myotis brandti & widespread & forest \\
\hline Myotis nattereri & widespread & forest \\
\hline Myotis schaubi & unknown & unknown \\
\hline Myotis blythi & warm & open \\
\hline Myotis daubentoni & widespread & water \\
\hline Myotis steiningeri & unknown & unknown \\
\hline Myotis dasycneme & cold & water \\
\hline Myotis bechsteini & widespread & forest \\
\hline Myotis praevius & unknown & unknown \\
\hline Myotis mystacinus & widespread & forest \\
\hline Plecotus abeli & unknown & forest \\
\hline Eptesicus nilssoni & cold & forest \\
\hline Miniopterus schreibersi & warm & open \\
\hline Rhinolophus mehelyi & warm & opportunist \\
\hline Rhinolophus macrorbinus & warm & opportunist \\
\hline Rhinolophus euryale & warm & forest \\
\hline Hypolagus beremendensis & unknown & open \\
\hline Hystrix sp. & unknown & open \\
\hline Spermophilus primigenius & unknown & open \\
\hline Sicista sp. & unknown & open \\
\hline Apodemus sylvaticus & widespread & opportunist \\
\hline Apodemus uralensis/sylvaticus & widespread & open \\
\hline Cricetus nanus & unknown & open \\
\hline Mimomys savini & unknown & water \\
\hline Mimomys pusillus & unknown & unknown \\
\hline Lagurodon arankae & unknown & open \\
\hline Microtus (Allophaiomys) pliocaenicus & unknown & unknown \\
\hline
\end{tabular}

are closed forest dwelling species. Their occurrence is often related to the proximity of water, but they are definitely attached to forests. Plecotus abeli may be the same indicator based on the occurrence of its living relatives. Rhinolophus mehelyi and $R$. macrorhinus are found in European karst areas and occur in grassy and wooded areas as well in warm climate (Table 2). 
In the Soricomorpha assemblage, Sorex minutus and Asoriculus gibberodon indicate humid, wooded or bushy environment (REUMER 1984, RZEBIK-KoWALSKA 2003). All the Crocidura species prefer warm climate, dry terrains, and open grasslands. Sorex runtonensis is an indicator of markedly cold and more or less open environment (Osipova et al. 2006). The presence of river or lakeside is marked by Desmana thermalis (RÜMKE 1985), Sorex (Drepanosorex) savini (Reumer 1984, Maul \& Parfitt 2010), and Beremendia fissidens (Botka \& Mészáros 2014). Petenyia is typified by Reumer (1984) as opportunist and ubiquitous genus (Table 2).

\section{RESULTS}

\section{Taxonomic results}

The analysis of the fauna from each individual sampling site revealed remarkable differences regarding the fossil richness and taxonomic composition of the assemblages (Table 1), thus it is desirable to compare the relative abundances of species and larger taxa in each of the sites with the others.

Regarding the fossil richness, there are sites with a sparse assemblage, with fewer than $10 \mathrm{MNI}$, like sites 4, 6, and 13/14. The material from such sites was excluded from the palaeoecological analysis. There are sites with an MNI between 10 and 50 (sites $1,3,7,8,10$, and 12/17), which provided a basis for a more reliable interpretation. Finally, there are sites with a rich assemblage (sites $2 / 15 / 16$, $5,9,11 / 18,19$, and 20), which allowed us to draw firm palaeoecological conclusions.

Regarding the faunal composition, there are sites with only bat remains (sites 6 and 13/14), but the MNI in these assemblages is extremely low (Table 1 ). There are sites, where bats and herpetofaunal elements are present (sites $2 / 15 / 16,4,10$, and 12/17), and there are sites, where other small mammals are also present besides the members of the two aforementioned groups (sites $1,3,5$, $7,8,9,11 / 18,19$, and 20 ).

Marked differences can be recognized regarding the relative abundance of individual species when comparing the different sampling sites. There is no dominant species among the herpetofaunal elements in the case of most samples (sites $1,2 / 15 / 16,3,4,5,6,7,8,10,12 / 17$, and 13/14). The green toad (Bufotes viridis) is dominant in site 9 and $11 / 18$, whereas remains belonging to the Pelophylax esculantus group are the most frequent in site 19 and 20. Comparing all samples, the most salamandrids (especially Lissotriton vulgaris) can be found in the assemblage from site 9. Apart from the latter, only a few salamandrids were found from sites $11 / 18,19$, and 20 . Turtles were only found in the assemblage from site 9. 
The most lacertid lizards were recovered also from site 9 . Only a few of them were found from sites $1,5,8,12 / 17,19$, and 20 . Among snakes, colubrids are relatively frequent, whereas vipers are rare. Members of the latter group were only found from sites 1, 5, 8, 9, and 11/18. The most frequent snakes in the assemblages are the dice snake (Natrix tesselata, especially from site 9) and the Aesculapian snake (Zamenis longissimus), but the grass snake (Natrix natrix) is relatively frequent as well.

No dominant small mammal species is present in the assemblages from sites 1 and 20. Most of the white-toothed shrews (Crocidurinae) were recovered from the latter two sites. However, the relative abundances of genera Crocidura, Beremendia, and Lagurodon are balanced in the case of site 1, slightly more Crocidura and Lagurodon, as well as Sorex runtonensis and Microtus (Allophaiomys) were found from site 20. The taxonomic composition of the two sites is similar, besides the already mentioned genera and species, both assemblages contain Sorex (Drepanosorex) savini, Apodemus sylvaticus, Mimomys savini, and Mimomys pusillus. There is no dominant bat in the assemblage recovered from site 1, but Myotis species dominate together in the case of site 20.

The relative abundance of Lagurodon and Microtus (Allophaiomys) is equal in the case of site 19, where, in addition, all three Sorex species and grassland dwelling small mammals including hares, voles, and hamsters are present in the same assemblage. The composition of the bat fauna of site 19 is very similar to that of site 20 .

Sites 5 and 8 are characterised by the dominance of Microtus (Allophaiomys), which was found together with relatively frequent Sorex and Beremendia remains. A notable abundance of Mimomys savini is present in the assemblage from site 5, whereas more hares and hamsters were found in the case of site 8. Only a few bats were found from these sites.

Lagurodon arankae is the dominant small mammal in the assemblages from sites 9 and 11/18. In addition, Crocidura is a relatively frequent remain from site 9, likewise, Sorex runtonensis and Sorex (Drepanosorex) savini from site 11/18. Both of the latter assemblages contain Sicista and Apodemus sylvaticus. The bat fauna of site 9 is sparse. Besides the dominance of Myotis species, the presence of water preferring forms with Mediterranean Rhynolophus and Miniopterus is notable in the assemblage from site $11 / 18$.

Sites $2 / 15 / 16$ and $12 / 17$ are dominated by warm preferring Rhynolophus bats, but a considerable amount of both grassland and forest Myotis species was also found. The dominance of the forest dwelling Myotis species is clear in the bat fauna of sites 3, 7, and 10.

Among shrews a Crocidura form was identified in sites 9 and 20, which could not be referred to any valid names. Nowadays, three Crocidura species 
are recognized from the European Early Pleistocene: Crocidura zorzii Pasa, 1942; Crocidura kornfeldi Kormos, 1934, and Crocidura obtusa Kretzoi, 1938 (Rofes \& CuenCA-Bescós 2011). C. zorzii is bigger than the specimens found in Beremend Crystal Cave. Botka \& MÉszáros (2015) showed that C. kornfeldi and C. obtusa can be distinguished mainly on the basis of the mandibular coronoid process. MÉszáros et al. (2019) confirmed this by redefining C. obtusa species. The structure of the coronoid process of specimens from sites 9 and 20 differs from both above mentioned shrews. Therefore, this form should be described as a new species. Unfortunately, the species level identification of jawless Crocidura remains is problematic, so they are mentioned here under the name, Crocidura sp. as well. We believe that no trouble is caused by using this contracted nomenclature in the conclusions, because the stratigraphic ranges of either the new species or the indeterminable specimens are similarly useless. Otherwise, the specific ecological characters of genus Crocidura allow us using these forms together in the palaeoecological reconstruction.

\section{Palaeoecological results}

The species richness of the herpetofauna is different comparing the individual sites. Three sites $(6,13 / 14$, and $2 / 15 / 16)$ did not contain herpetofaunal elements at all. The heliophilous animals (e.g., Bufotes viridis and Lacerta viridis) are frequent $(57 \%)$ in the studied samples, but the water preferring species (e.g., Pelophylax esculentus group and Natrix tesselata) are not rare either (31\%). This latter group primarily appears in sites $5,9,11 / 18$, and 20 . The burrowing green toad (which is more active at night) is the most frequent in the case of sites 9 and $11 / 18$ comparing all assemblages. The relative abundance of both forest dwelling animals (e.g., Rana dalmatina and Zamenis longissimus) and opportunists (e.g., Rana temporaria and Coronella austriaca) is $6 \%$ in the case of these two sites. The forest dwelling Rana dalmatina appears only in the assemblages from sites 11/18 and 19, whereas most of the remains of Zamenis longissimus was found from site 9. Opportunist taxa are not frequent; Rana temporaria is present in the assemblages from sites 11/18 and 19, whereas Coronella austriaca only appears in the case of site 9 .

The above mentioned data suggest that the history of the herpetofauna can be divided into several stages, which can be correlated with the changes recognized in the case of the chiropteran assemblages (see below). However, it can be concluded that a permanent water body was near the Beremend Crystal Cave during the Early Pleistocene, but its size may have changed during the studied period due to changing climate. The periodic appearance of opportunist taxa may be related to these changes. 
Among shrews of the Beremend Crystal Cave, the dominance of the warm grassland indicator Crocidura is conspicuous in site 9. Asoriculus gibberodon and Sorex minutus, which prefer closed forests and scrubland environment, occur in several sites, but much less frequently. Their relative abundance is similar to that of aquatic insectivores (D. thermalis, $S$. (D.) savini and Beremendia). S. runtonensis, living in cold steppe areas, is hardly present in the assemblage, compared to its abundance in other Early Pleistocene localities.

Most of the Beremend 16 bat species prefer warm climate. We found only few species that are especially cold tolerant in some of the sites. Most of them are inhabitants of more or less closed forests or scrubby areas, while indicators of open vegetation are less frequent. Many of them like to hunt over larger water surfaces. The bat fauna refers to a mosaic ecotype along a larger body of water in a moderately warm climate.

Among lagomorphs and rodents from the locality, only a few are indicative of the environment. But most of these indicate an open grassland environment (Hypolagus beremendensis, Hystrix sp., Spermophilus primigenius, Sicista sp., Apodemus uralensis, Cricetus nanus). Among arvicolids, only the ancient water vole, Mimomys savini and a lagurid, Lagurodon arankae can be used as an environmental indicator.

Taking into account the entire small vertebrate fauna of the assemblages and the environmental preferences of the taxa (Table 2), a palaeoclimatic and vegetational reconstruction could be made for almost all sites within the Beremend Crystal Cave. In order to draw such conclusions, the number (Tables 3-4) and relative abundance (Figs 2-3) of the environmental indicator taxa were considered. Those sites, where the MNI was lower than 10, were excluded from the palaeoecological analysis (sites 4, 6, 13/14). Based on this analysis, the following environments can be differentiated:

1. Cold, dry climate, open vegetation with a close proximity of a relatively large water body (sites 5 and 8). Although the richness of these sites (22-26 species) is sufficient, it has to be taken into consideration that most of the taxa are widespread, thus especially the climatic reconstruction might not be reliable.

2. Temperate, dry climate, grassland with slightly more closed patches. The size of the water body was probably somewhat smaller than above (sites 1 , $11 / 18,19$, and 20). These assemblages are rich, with more than 30 species. A lot of the recovered taxa are indicative of the environment and the climate, thus these conclusions are reliable.

3. Temperate, dry climate with primarily closed vegetation. Most likely, only a small water body was present in the vicinity (sites 3,7 , and 10). The species 


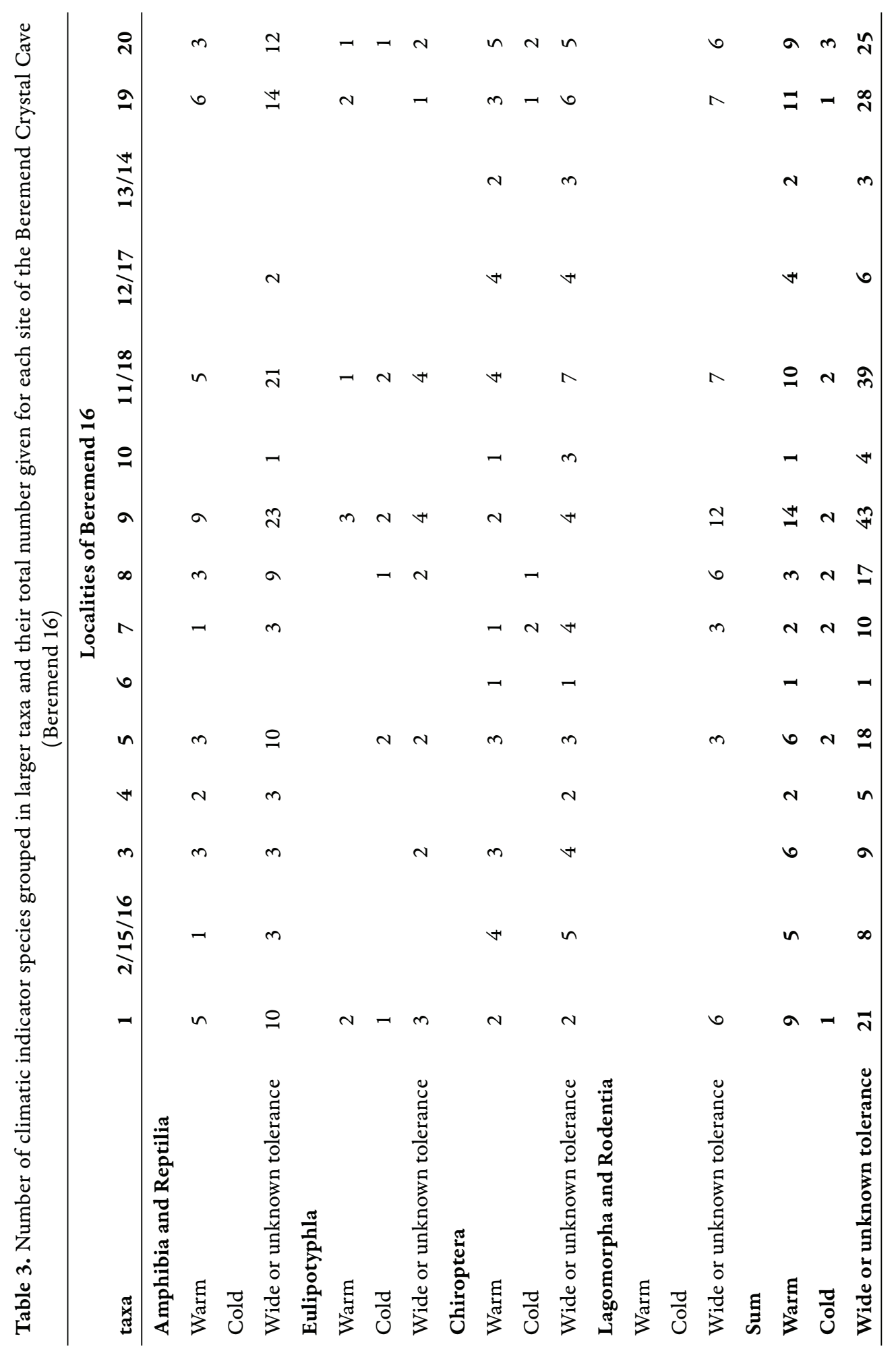




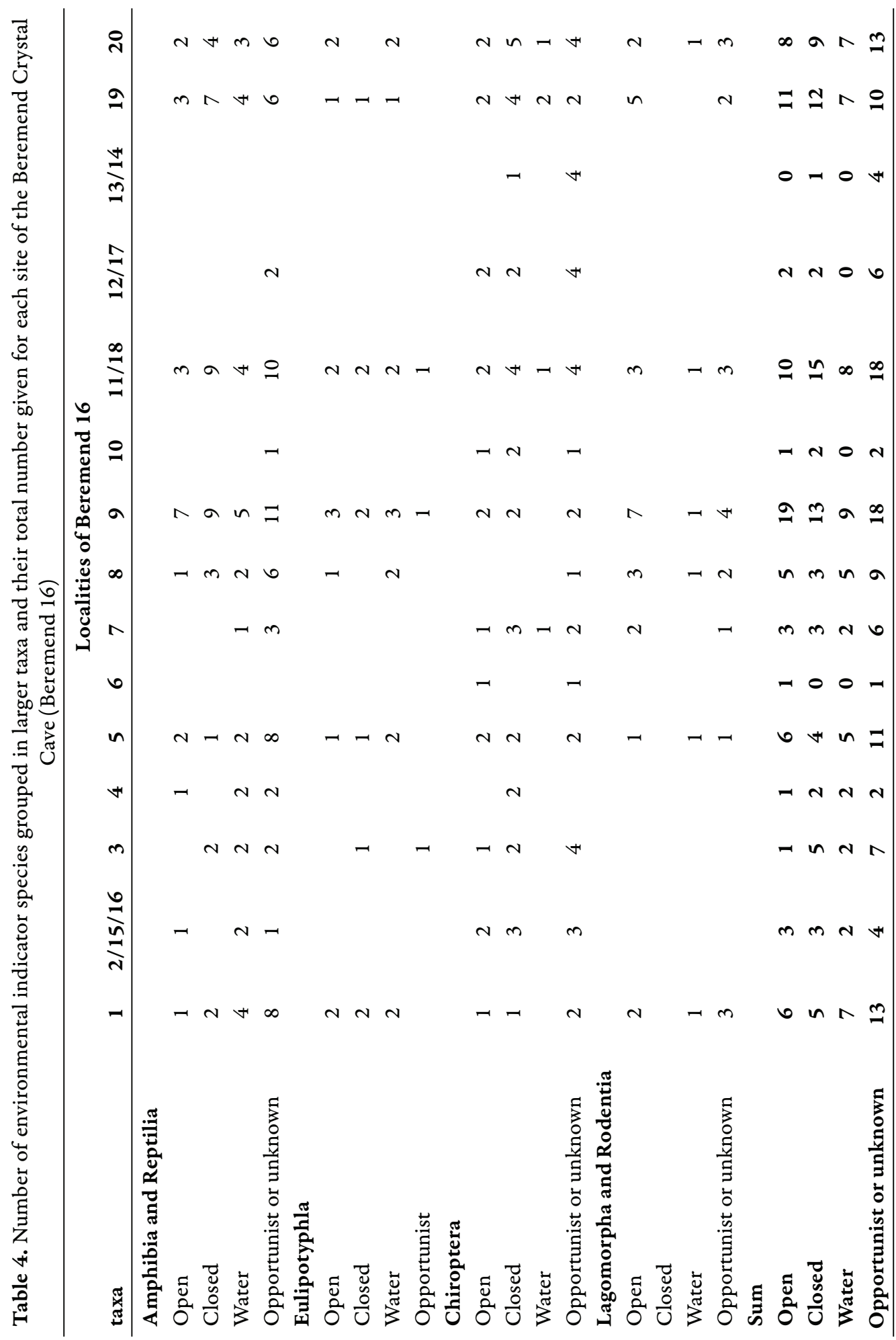




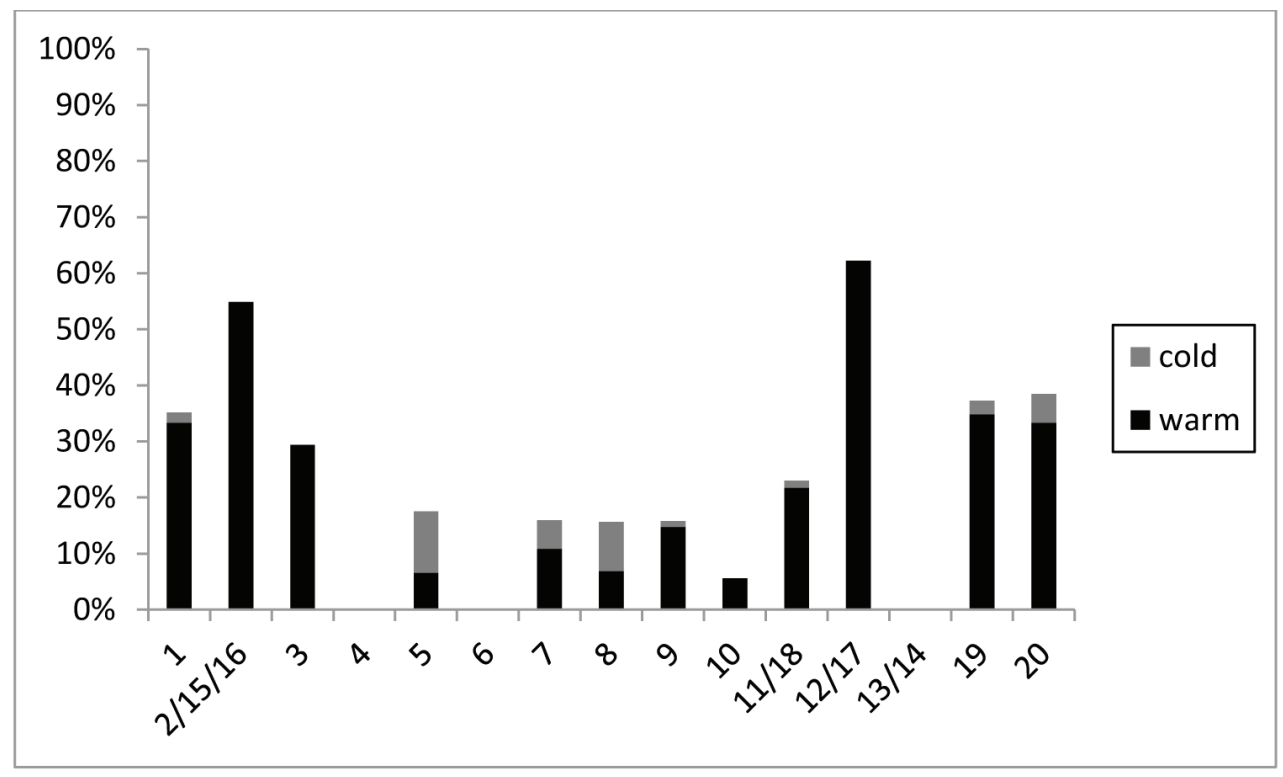

Fig. 2. Relative abundance of the climatic indicator taxa compared to the entire recovered assemblage of each site

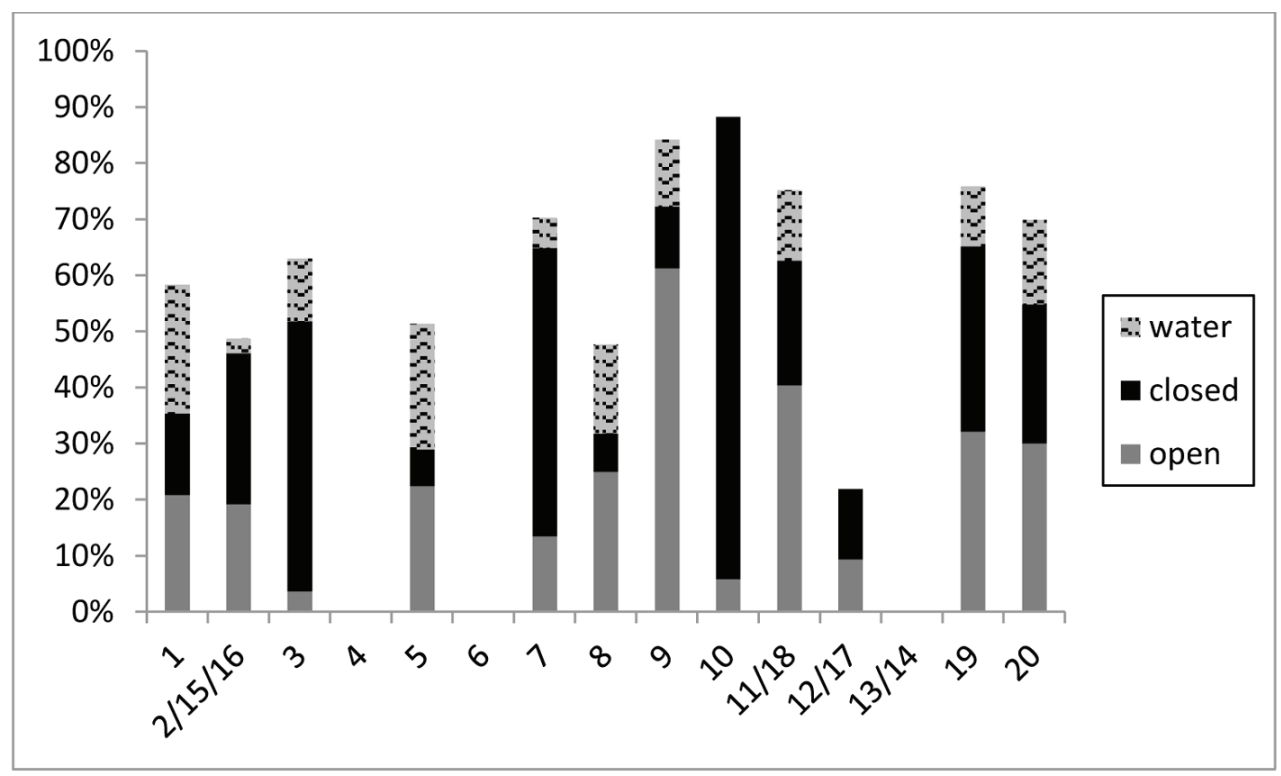

Fig. 3. Relative abundance of the environmental indicator taxa compared to the entire recovered assemblage of each site 
richness is low, climatic indicator taxa are sparse, thus these conclusions are less reliable than above.

4. Temperate, dry climate, open vegetation with a medium-sized water body (site 9). Extremely rich assemblage with more than 50 species, however, the number of climatic indicator taxa is low, thus these conclusions might not be reliable.

5. Warm, dry climate with the dominance of more closed vegetation. The water body was probably small (sites $2 / 15 / 16$ and $12 / 17$ ). The species richness is low, although climatic indicator taxa are abundant, environmental indicators are sparse, thus the environmental reconstruction might not be reliable.

\section{Stratigraphic results}

Most of the Eulipotyphla species of Beremend Crystal Cave are too longranged for using them in a stratigraphic investigation. Sorex minutus appeared in the Early Pliocene MN 14 zone and is still living (RZEBIK-KowALSKa 1991). Similarly, the oldest record of Sorex runtonensis can be dated back to the Late Pliocene, whereas the youngest ones are known from several Late Pleistocene localities (Osipova et al.2006). Beremendia fissidens is also reported from the MN 14 zone up to the Tarköian Phase of the Middle Pleistocene in Europe (BоткA \& MÉszÁros 2014). Desmana thermalis emerged at the beginning of the Early Pleistocene (MN 17 zone) and disappeared at the end of the Late Pleistocene (RÜMKE 1985) (Fig. 4).

Based on some of the shrew remains, however, we can conclude that the sites are not younger than the end of the Early Pleistocene. The stratigraphic range of Petenyia hungarica spans from the Miocene/Pliocene boundary (MN13/14 zone) up to the end of the Early Pleistocene (Rzebik-Kowalska 2000) (Fig. 4). The first occurrence of Asoriculus gibberodon in Hungary is reported by MÉszÁROS (1998) from the Late Miocene MN 12 zone, and it disappears only at the end of the Early Pleistocene (RzEBiK-Kowals Ka 2000). The Early Pleistocene age of the sites is supported by the occurrence of Sorex (Drepanosorex) savini, which is reported from the Early Pleistocene MN 17 zone until the Late Biharian Stage of the Middle Pleistocene (Вот Ka \& MÉszáros 2016).

Crocidura obtusa seems to be the most useful shrew for making stratigraphic conclusions, because it was present in Central Europe from the late Early Pleistocene $(1.2 \mathrm{Ma})$ to the earliest Late Pleistocene (BOTKA \& MÉszÁros 2015). Therefore, on the basis of its occurrence, we can determine the age of some sites as the second half of the Biharian Age.

The Pleistocene chiropteran assemblages are less useful for drawing stratigraphic conclusions than for presuming ecological conditions, because their 
elements hardly changed since the Pliocene. The bat species identified from Beremend Crystal Cave support the conclusions drawn from other fauna elements (Woloszyn 1987; Topál 1989; TraVNiCKOVA 2016).

The genera Myotis, Rhinolophus, Eptesicus, Miniopterus, and Plecotus have been present since the Miocene or the Early Pliocene. Among the species, $M$. bechstein, $M$. blythii, M. daubentoni, M. emarginatus, M. mystacinus, and $M$. nattereri appeared in MN 15, while $M$. brandti, $M$. dasycneme, and $M$. schaubi emerged in MN 17. Based on their presence, the fauna cannot be older than the Early Pleistocene.

There are three species in the fauna that occur only in the Biharian Age in the Carpathian Basin: Eptesicus nilssoni, Miniopterus schreibersi, and Plecotus abe$l i$. These species suggest that sites $2 / 15 / 16,5,7,9,11 / 18,12 / 17,19$, and 20 are from the second part of the Early Pleistocene.

The only short-ranged form from the locality is the group identified by György Topál as $M$. "praevius ssp." at site 1, which species is reported from the MN 16-17 zones. This would be difficult to interpret considering the stratigraphic view formed on the basis of the overall fauna. But in our opinion, until finding further morphological evidence for a grounded separation of this species from the Early Pleistocene $M$. praevius, this temporary solution would help to avoid unnecessary confusion related to the range of the latter taxon.

In the age determination of the sites where small mammals were found, rodents and large mammals play an important role as well. Among rodents, voles (Mimomys savini, M. pusillus, Microtus (Allophaiomys) pliocaenicus, Lagurodon arankae) clearly indicate an Early Pleistocene age. Lagurodon arankae appeared 2.0 Ma, M. pusillus and M. savini emerged $1.8 \mathrm{Ma}$, whereas the first Microtus (Allophaiomys) pliocaenicus remains can be dated back to only much later, to 1.5 Ma (MAul \& Markova 2007; Tesakov 2004). Their co-occurrence indicates that the sites are younger than $1.5 \mathrm{Ma}$ (Fig. 4). These voles (apart from M. savini) disappeared around the Early/Middle Pleistocene boundary. Therefore, those sites, where $M .(A$.) pliocaenicus was found (sites 1, 5, 7, 8, 9, 11/18, 19, and 20), can be dated between $1.5 \mathrm{Ma}$ and $0.78 \mathrm{Ma}$. Because neither Microtus (Terricola) nor Prolagurus remains were found at the sites, the members of which genera appeared around 1.1 Ma and 1.2 Ma, respectively (MAUL \& MARKova 2007; TESAKOV 2004), the age of the sites is probably older than these dates.

Among large mammals, Homotherium crenatidens appeared $1.35 \mathrm{Ma}$ (Diedrich \& MCFARLANe 2017), thus those sites where fossils of this particular species were found (sites $7,11 / 18$ and 19), are probably younger than this date (Fig. 4).

In conclusion, the age of the sites within the Beremend Crystal Cave can be correlated with the late Early Pleistocene. The sites can be dated back between 


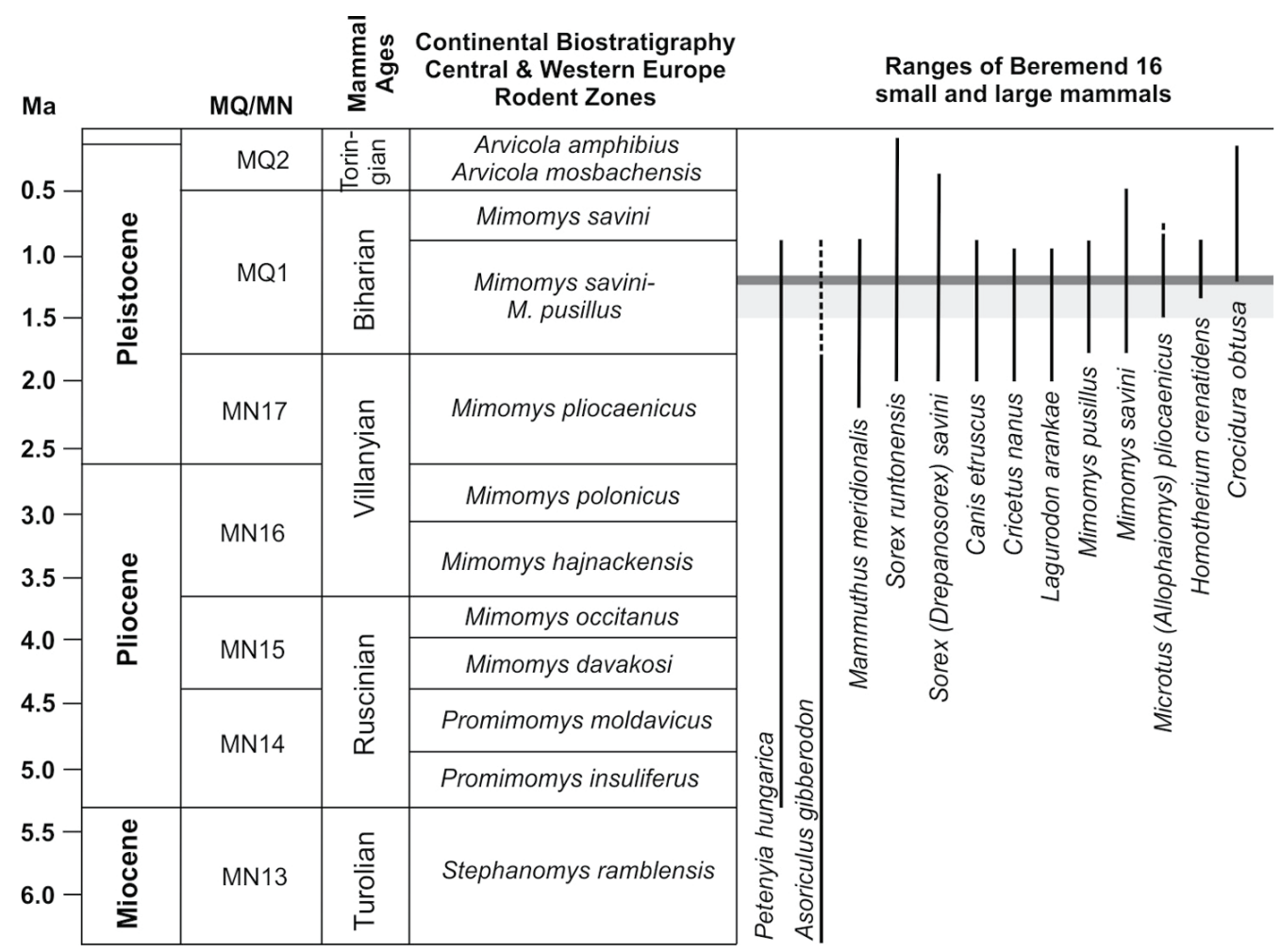

Fig. 4. Stratigraphically important small and large mammal taxa of Beremend Crystal Cave (Beremend 16). The most probable age of the older sites is indicated by a light grey zone, whereas age of the younger sites is marked with dark grey (after MCGowRAn \& DENBIGH 2008; TeSAKov 2004)

1.5 Ma and 1.2 Ma. Within this time period, older and younger sites can be separated based on the ranges of the mammals in their fauna. The material of the older sites can be dated between 1.5-1.2 Ma (sites 5, 8, and 20) and 1.35-1.2 Ma (sites $7,11 / 18$, and 19). The material of the younger sites ( 1 and 9) accumulated approximately $1.2 \mathrm{Ma}$, as indicated by the presence of Crocidura obtusa, which just appeared around that date (Fig. 4).

\section{CONCLUSIONS}

Based on our thorough taxonomic, palaeoecological and stratigraphic analysis of the samples collected from 15 different sites within the Beremend Crystal Cave, it can be concluded that these assemblages cannot be unified and interpreted as a whole, because of several considerable differences that were pointed out here regarding their faunal content, their age, and the former environment they represent. 
Diverse and sparse assemblages were recognized based on the fossil richness and taxonomic composition of the samples from each site. Some of these assemblages contain only bats, whereas others contain other small mammals and herpetofaunal elements as well. These dissimilarities exist probably due to taphonomical or age differences.

Apart from the appearance of Crocidura obtusa, no relevant evolutionary or faunistical event can be identified in the assemblages, thus it can be assumed that the age difference between the sites is minor. According to the results of the detailed stratigraphic analysis, which was based on the ranges of the mammal taxa found within the assemblages, the sites can be divided into an older and a younger group. The material of the older sites can be dated between 1.5-1.2 Ma (sites 5, 8, and 20) and 1.35-1.2 Ma (sites 7, 11/18, and 19), whereas the material of the younger sites ( 1 and 9 ) accumulated approximately $1.2 \mathrm{Ma}$, as indicated by the presence of Crocidura obtusa.

The palaeoecological study of the small vertebrate fauna showed that the material of the different sites accumulated under distinct palaeoenvironmental conditions, which also confirms that not all of the sites are contemporaneous. It can also be concluded that a water body varying in size was in the close proximity of the cave during the entire studied time period. The lake was surrounded by open or sometimes more closed vegetation depending on the changes of the erstwhile climate.

Based on the assemblages older than $1.2 \mathrm{Ma}$, the following three environments were recognized:

1. Cold and dry climate, open vegetation with the close proximity of a relatively large water body (1.5-1.2 Ma). Most likely a grassland, which was present during the accumulation of the fossils at sites 5 and 8 .

2. Temperate and dry climate, primarily open vegetation and the close proximity of a relatively large water body $(1.35-1.2 \mathrm{Ma})$. These suggest a grassland environment with woodland patches. These conditions were present during the accumulation of the fossils at sites 11/18, 19, and 20.

3. Temperate and dry climate, primarily closed vegetation with only a small water body in the vicinity (1.35-1.2 Ma). This woodland environment was reconstructed based on the material of sites 3 and 7. Site 10, which has an uncertain age and contains only bats and herpetofaunal elements, is also indicative of a warm environment with closed vegetation, thus it was tentatively assigned here.

Based on the assemblages of the younger sites, which have an age of approximately 1.2 $\mathrm{Ma}$, the following two environments were recognized: 
1. Temperate and dry climate, open vegetation with only a small water body in the vicinity. Site 9 belongs to this group, in which grassland dwelling species are dominant.

2. Temperate and dry climate, primarily open vegetation with woodland patches. Site 1 belongs to this group, of which environment is essentially identical to that of group 2 in the case of the older sites.

Among the 12 assemblages that were included in the stratigraphic and palaeoecological analyses, two (sites $2 / 15 / 16$ and $12 / 17$ ) contained only bats and herpetofaunal elements, thus their age and the environment, in which they were formed, are uncertain. These assemblages are characterised by low species number, however, warm preferring taxa are dominant and the relative abundance of taxa indicative of a closed vegetation is slightly higher than the relative abundance of those which preferred open environments. These most likely suggest a grassland environment with woodland patches for these sites.

Acknowledgements - The authors are grateful to the reviewers of this paper, as well as to István Vörös for his original notes, Eszter Hankó for identifying the Homotherium material, and Attila Virág for his invaluable comments, which helped to improve the manuscript. Thanks are due to Mihály Gasparik for providing access to the material stored in the collections of the Hungarian Natural History Museum. This is Paleo contribution No. 312.

\section{REFERENCES}

Arnold E. N. \& Ovenden D. N. 2002: Field Guide: Reptiles \& Amphibian in Europe \& GreatBritain. - Collins \& Co., London, 208 pp.

Bihari Z., Csorba G. \& Heltai M. 2007: Magyarország emlöseinek atlasza. - Kossuth Kiadó, Budapest, $360 \mathrm{pp}$.

Blain H.-A. \& Villa P. 2006: Amphibians and squamata reptiles from the early Upper Pleistocene of Bois Roche Cave (Charante, southwestern France). - Acta Zoologia Cracoviensa 49A(1-2): 1-32. https://doi.org/10.3409/000000006783995517

Bot Ka D. \& MÉszÁros L. 2014: Beremendia (Mammalia, Soricidae) remains from the late Early Pleistocene Somssich Hill 2 locality (Southern Hungary) and their taxonomic, biostratigraphical, palaeoecological and palaeobiogeographical relations. - Fragmenta Palaeontologica Hungarica 31: 83-115. https://doi.org/10.17111/FragmPalHung.2014.31.83

Bot ka D. \& MÉszáros L. 2015: Crocidura (Mammalia, Soricidae) remains from the late Early Pleistocene Somssich Hill 2 locality (Villány Hills, Southern Hungary). - Fragmenta Palaeontologica Hungarica 32: 67-98. https://doi.org/10.17111/FragmPalHung.2015.32.67

Bot Ka D. \& MÉszÁros L. 2016: Sorex (Mammalia, Soricidae) remains from the late Early Pleistocene Somssich Hill 2 locality (Villány Hills, Southern Hungary). - Fragmenta Palaeontologica Hungarica 33: 135-154. https://doi.org/10.17111/FragmPalHung.2016.33.135 
Böhme M., Ilg A., Ossig A. \& KüChenhoff H. 2006: New method to estimate paleoprecipitation using fossil amphibians and reptiles in the middle and late Miocene precipitation gradients in Europe. - Geology 34(6): 425-428.

https://doi.org/10.1130/G22460.1

Carisio L., Sacchi R., Seglie D. \& Sindaco R. 2014: Habitat selection in the fossorial toad Pelobates fuscus insubricus (Amphibia: Pelobatidae): does the soil affect species occurrence? - Acta Herpetologica 9(1): 51-59. https://doi.org/10.13128/Acta_Herpetol-12667

CsÁszár G. \& Kordos L. 2004: Beremend kőfejtő [Beremend Quarry]. - Program, elöadáskivonatok, kirándulásvezetö, 7. Magyar Öslénytani Vándorgyülés, Beremend 2004. május 6-8, pp. 51-57.

DENOËL M. 2004: Distribution and characteristics of aquatic habitats of newts and Yellow-bellied toads in the district of Ioannina (Epirus, Greece) (Amphibia: Caudata: Salamandridae; Anura: Discoglossidae). - Herpetozoa 17(1/2): 49-64.

Diedrich C. G. \& McFarlane D. A. 2017: Homotherium from Middle Pleistocene archaeological and carnivore den sites of Germany - Taxonomy, taphonomy and a revision of the Schöningen, West Runton and other saber-tooth cat sites. - Quaternary International 436: 76-83. https://doi.org/10.1016/j.quaint.2016.10.015

Duguet R. \& Melki F. 2003: Les Amphibiens de France, Belgique et Luxemburg. - Collection Parthénope, editions Biotop, Mèze (France), 480 pp.

Eggert C. 2002: Le déclin la Pélobate drun (Pelobates fuscus, Amphibien Anoure): de la biologie de las populations à structuration génétique. - Bulletin de la Société zoologique de France 127(3): 273-279.

Gunnell G. F., Eiting T. P. \& Geraads D. 2011: New late Pliocene bats (Chiroptera) from Ahl al Oughlam, Morocco. - Neues Jahrbuch für Geologie und Paläontologie - Abhandlungen 260(1): 55-71. https://doi.org/10.1127/0077-7749/2011/0128

Jánossy D. 1986: Pleistocene vertebrate faunas of Hungary. - Akadémiai Kiadó, Budapest and Elsevier Sciences Publishers, Amsterdam, Oxford, New York, Tokyo, 208 pp.

JÁnossy D. 1992: Lower Pleistocene bird remains from Beremend (S-Hungary, Loc. 15 and 16). Aquila 99: 9-25.

JÁnossy D. 1996: Lower Pleistocene vertebrate faunas from the localities 16 and 17 of Beremend (Southern Hungary). - Fragmenta Mineralogica et Paleontologica Hungarica 18: 91-102.

JÁnossy D. \& TopÁl Gy. 1985: Palaeontological remains from the Cave Loc. 16-17 Beremend. - In: TAKÁcs-Bolner K. (ed.): The Crystal Cave at Beremend. - Karszt és Barlang, Special issue 1985: 10-11.

Jánossy D., Topál Gy. \& VöRös I. 1987: Jelentés a Beremendi-kristálybarlangból (B-16) gyüjtött gerinces ösmaradványokról. [Report about vertebrate fossils of the Beremend Crystal Cave (B16).] - Manuscript, Budapest, 19 pp.

Kordos L. 1991: Villányi-hegység, Beremend, felső-pliocén ősgerinces lelőhelyek. [Villány Hills, Beremend, Upper Pliocene vertebrate localities.] - Magyarország Geológiai Alapszelvényei, Magyar Állami Földtani Intézet, Budapest, pp. 1-6.

Kretzor M. 1956: A Villányi-hegység alsó-pleisztocén gerinces faunái. (Die Altpleistozänen Wirbeltierfaunen des Villanyer Gebirges). - Geologica Hungarica series Paleontologica 27: 1-264.

KRETzOI M. 1969: A magyarországi quarter és pliocén szárazföldi biosztratigráfiájának vázlata. [Sketch of the Quaternary and Pliocene terrestrial biostratigraphy in Hungary.] - Földrajzi Közlemények 17: 179-204.

Kretzoi M. \& PÉCsi M. 1982: A Pannóniai-medence pliocén és pleisztocén időszakának tagolása. [Division of the Pliocene and Pleistocene in the Pannonian Basin.] - Földrajzi Közlemények 30(4): 300-326. 
Krolopp E. 1990: Die Molluskenfaunen der unterpleistozänen Fundstellen Ungarns. - Quartärpaläontologie 8: 125-130.

MAUL L. C. \& MAR Kova A. K. 2007: Similarity and regional differences in Quaternary arvicolid evolution in Central and Eastern Europe. - Quaternary International 160: 81-99. https://doi.org/10.1016/j.quaint.2006.09.010

Maul L. C. \& Parfitt S. A. 2010: Micromammals from the 1995 Mammoth Excavation at West Runton, Norfolk, UK: Morphometric data, biostratigraphy and taxonomic reappraisal. Quaternary International 228(1): 91-115. https://doi.org/10.1016/j.quaint.2009.01.005

McGowran B. \& Denbigh K. G. 2008: Biostratigraphy: Microfossils and Geological Time. Cambridge University Press, 480 pp.

Mészáros L. Gy. 1998: Late Miocene Soricidae (Mammalia) fauna from Tardosbánya (Western Hungary). - Hantkeniana 2: 103-125.

MÉszÁros L., BotKa D. \& GaSparik M. 2019: Establishing a neotype for Crocidura obtusa Kretzoi, 1938 (Mammalia, Soricidae): an emended description of this Pleistocene whitetoothed shrew species. - Paläontologische Zeitschrift 94, https://doi.org/10.1007/s12542-019-00458-x

Miró A., O’Brian D., HALl J. \& JeHLE R. 2016: Habitat requirements and conservation needs of peripheral populations: the case of the great crested newt (Triturus cristatus) in the Scottish Highlands. - Hydrobiologia 792(1): 169-181. https://doi.org/10.1007/s10750-016-3053-7

Osipova V. A., Rzebik-Kowalska B. \& Zaitsev M. V. 2006: Intraspecific variability and phylogenetic relationships of the Pleistocene shrew Sorex runtonensis (Soricidae). - Acta theriologica 51(2): 129-138. https://doi.org/10.1007/BF03192664

PAZonyi P., MészÁros L., Hír J. \& Szentesi Z. 2016: Lowermost Pleistocene rodent and sorocid (Mammalia) fauna from Beremend 14 locality (South Hungary) with biostratigraphical and paleoecological implications. - Fragmenta Paleontologica Hungarica 33: 99-134. http://doi.org/10.17111/FragmPalHung.2016.33.99

PeténYi S. J. 1864: Hátrahagyott munkái. [Posthumous works]. - Magyar Tudományos Akadémia, Pest, 130 pp.

PONGRÁCz L. 1999: A beremendi Szőlö-hegy természettudományi kutatásának 150 éve. [Natural sciences research of the Szölö Hill, Beremend during the last 150 years]. - Petényi Emlékkönyv, Beremend, $149 \mathrm{pp}$.

Popov V. V. 2004: Pliocene small mammals (Mammalia, Lipotyphla, Chiroptera, Lagomorpha, Rodentia) from Muselievo (North Bulgaria). - Geodiversitas 26(3): 403-491.

Reumer J. W. F. 1984: Ruscinian and early Pleistocene Soricidae (Insectivora, Mammalia) from Tegelen (The Netherlands) and Hungary. - Scripta Geologica 73: 1-173.

Rofes J. \& CuenCA-Bescós G. 2011: Evolutionary history and biogeography of the genus Crocidura (Mammalia, Soricidae) in Europe, with emphasis on Crocidura kornfeldi. - Mammalian Biology 76(1): 64-78. http://doi.org/10.1016/j.mambio.2009.12.001

RÜMKe C. G. 1985: A review of fossil and recent Desmaninae (Talpidae, Insectivora). -Utrecht Micropaleontological Bulletins 4: 1-241.

Rzebik-Kowals Ka B. 1991: Pliocene and Pleistocene Insectivora (Mammalia) of Poland. VIII. Soricidae: Sorex Linnaeus, 1758, Neomys Kaup, 1829, Macroneomys Fejfar, 1966, Paenelimnoecus Baudelot, 1972 and Soricidae indeterminata. - Acta zoologica cracoviensia 34(2): 323-424.

Rzebi K-Kowals Ka B. 2000: Insectivora (Mammalia) from the Early and early Middle Pleistocene of Betfia in Romania. I. Soricidae Fischer von Waldheim, 1817. - Acta zoologica cracoviensia 43(1-2): $1-53$. 
Rzebik-Kowalska B. 2003: Distribution of shrews (Insectivora, Mammalia) in time and space. - Deinsea 10(1): 499-508.

Szentesi Z. 2016: Hasonlóságok és különbségek a Beremend 16-os és 17-es alsó-pleisztocén lelőhelyek (Villányi-hegység) herpetofaunájában. [Similarities and differences in herpetofauna of lower Pleistocene Beremend 16 and 17 localities (Villány Hills).] - In: ViráG A. \& Bosnakof m M. (eds): Program, Előadáskivonatok, Kirándulásvezetö, 20. Magyar Öslénytani Vándorgyülés, Tata-Tardos, 2017, pp. 44-45.

TAKÁCs-Bolner K. 1986: A Beremendi-kristálybarlang. [Beremend Crystal Cave.] - Karszt és Barlang 1985(1-2): 3-12.

Tesakov A. S. 2004: Biostratigraphy of Middle Pliocene - Eopleistocene of Eastern Europe (based on small mammals). - Moscow, Nauka, 247 pp. [in Russian]

Thirion J.-M., Grillet P. \& Greniez P. 2002: Les Amphibiens et les Reptiles du centre-ouest de la France, région Poitou-Charantes et départements limitrophes. - Collection Parthénope, editions Biotope, Mèze (France): 144 pp.

Topál Gy. 1989: Tertiary and Early Quaternary remains of Corynorbinus and Plecotus from Hungary (Mammalia, Chiroptera). - Vertebrata Hungarica 23: 33-55.

Travnickova E. 2016: Mid-European bat fauna along the Pliocene/Pleistocene boundary: genus Myotis. - PhD dissertation, Charles University, Prague, $141 \mathrm{pp}$.

Trembeczki M., Mészáros L., Szentesi Z. \& PAzonyi P. 2018: Kora-pleisztocén környezet-rekonstrukciók a beremendi Kristály-barlang (Beremend 16) gerinces faunáinak paleoökológiai elemzése alapján. [Early Pleistocene environmental reconstructions based on paleo-ecological analysis of vertebrate fauna of the Crystal Cave of Beremend (Beremend 16).] - In: Virág A. \& Bosnakoff M. (eds): Program, Elöadáskivonatok, Kirándulásvezető, 21. Magyar Öslénytani Vándorgyülés, Félixfürdő (Románia), pp. 31-32.

Vigassy T., LeÉL-Össy Sz. \& DEMÉNY A. 2010: A Nagyharsányi- és a Beremendi-kristálybarlang és képződményeik genetikai vizsgálata. [The crystal caves of Nagyharsány and Beremend, and genetic investigation of their precipitations.] - Földtani Közlöny 140(1): 73-88.

Woloszyn B. W. 1987: Pliocene and Pleistocene bats of Poland. - Acta Palaeontologica Polonica 32(3-4): 207-325.

Žagar A., Krofel M., Govedič M. \& Mebert K. 2011: Distribution and Habitat Use of Dice Snakes (Natrix tesselata) in Slovenia. - Mertensiella 18: 207-216. 